\title{
РОЗВИТОК САМОСТІЙНОСТІ СТУДЕНТІВ ВНЗ ЯК КОМПОНЕНТА ЇХ КУЛЬТУРИ ПРАЦІ
}

Серьогіна І. Ю. Розвиток самостійності студентів ВНЗ як компонента їх культури праці.

У статті представлено шляхи розвитку самостійності студентів ВНЗ як компонента їхньої культури праці; запропоновано прийоми розвитку самостійності студентів ВНЗ; виявлено динаміку інтенсивної, ситуативної та епізодичної частоти виявів самостійності студентів у навчальній діяльності.

Ключові слова: культура праці, самостійна діяльність, метод смислової регуляції, професійний розвиток студентів.

Серёгина И. Ю. Развитие самостоятельности студентов высших учебных заведений как компонента культуры их труда.

В статье представлены пути развития самостоятельности студентов высших учебных заведений как компонента культуры их труда; предложены приёмы развития самостоятельности студентов высших учебных заведений; выявлена динамика интенсивной, ситуативной и эпизодической частоты проявлений самостоятельности студентов в учебной деятельности.

Ключевые слова: культура труда, самостоятельная деятельность, метод смысловой регуляции, профессиональное развитие студентов.

Seryogina I. Y. Development of higher school students' independence as a component of work culture.

The article presents the ways of developing higher school students' independence as a component of work culture; offers the methods of developing higher school students' independence; reveals the dynamics of intensive, situational and occasional demonstration of students' independence in their learning activities.

Key words: work culture, independent activity, the method of sense regulation, professional development of students.

У сучасних умовах реформування освіти актуальними $є$ проблеми підготовки зрілої, цілісної особистості, яка повинна вміти аналізувати ті чинники, що матимуть найістотніший вплив на проектоване нею виробництво, прогнозувати перспективи його майбутнього розвитку, здійснювати відповідні розрахунки. Сучасний фахівець має відчути себе кваліфікованим підприємцем, господарем, здатним визначити найдоцільніший виробничий напрям, аналізувати результати власної виробничої діяльності тощо. Необхідно зазначити: щоб людина змогла відбутися як особистість, процес іiї навчання повинен бути нерозривно пов'язаний із моральним вихованням, що допоможе їй зайняти гідне місце в суспільному житті, самостійно зробити вибір, визначити власну життєву позицію.

У XX столітті видатні науковці П. Блонський, А. Макаренко, В. Сухомлинський, с. Шацький здійснювали дослідження в галузі трудового навчання і виховання молодого покоління. Вони справедливо стверджували, що професійне навчання i виховання повинно допомогти виявити в особистості активність, 
самостійність, прагнення перетворити думку в дію, завдання викладача у цьому контексті - знайти цікавий матеріал для самостійних занять. Окрім того, доречною $є$ думка С. Шацького, який підкреслював важливість індивідуального розвитку фахівця: «... головним для людини є можливість працювати і використовувати свої знання для здійснення простих життєвих завдань, працювати фізично і розумово, складати план своєї роботи і перевіряти його на ділі» [3, с. 295]. Ми поділяємо думку автора по те, що такий підхід забезпечує можливість особистісного розвитку, формування культури праці особистості та стимулює реалізацію їі творчих сил.

Аналіз робіт зазначених науковців дозволив виявити суперечність між роллю колективного виховання культури праці та індивідуально-особистісним підходом, актуальними постають питання оптимального співвіднесення двох аспектів цілісного процесу формування самостійності особистості як компонента культури праці і професійного розвитку студентів вищого навчального закладу.

Метою статmi $\epsilon$ розгляд та характеристика процесу розвитку самостійності студентів як компонента їхньої культури праці (на прикладі технолого-педагогічного факультету педагогічного інституту).

Розглянувши різні погляди науковців, у контексті нашого дослідження ми вважаємо, що пріоритетними напрямом навчально-виховної роботи у ВНЗ в умовах переходу до ринкової економіки повинно стати професійне навчання і виховання, яке не слід ототожнювати 3 поняттям «трудове виховання», компонентами якого $\epsilon$ формування позитивного ставлення до праці та професійна орієнтація студентів.

Досліджуючи шляхи формування культури праці, ми акцентуємо увагу на розвиток самостійності та професійних інтересів студентів у навчально-виробничій діяльності. Адже формування самостійності у майбутніх фахівців технологічного профілю - найважливіше завдання їхнього професійного становлення. Самостійну роботу в контексті нашого дослідження ми розглядаємо як один із засобів організації навчально-виробничої діяльності студентів із засвоєння знань і виконання завдань 3 оволодіння знаннями, вміннями, навичками, прийомами творчої праці. Самостійна діяльність інтегрує результати зовнішнього впливу на особистість і процеси внутрішніх особистісних перетворень; саме це впливає на формування професійного інтересу. Ми виокремили 2 групи чинників інтегрованого впливу:

1 група - висока продуктивність і культура праці учасників навчальновиробничого процесу; задоволення від успішної роботи; можливість реалізації власних професійних якостей у самостійній праці.

2 група - особистість викладача ВНЗ, традиції навчального закладу, оснащення аудиторій та майстерень, участь студентів в інших видах позанавчальної діяльності.

Самостійна робота сприяє активному формуванню трудових умінь і навичок для успішного виконання завдання. На цьому етапі, крім трудових умінь, виявляються нахили та здібності, які можна скорегувати. 3-поміж загальнотрудових умінь інтелектуального характеру (визначення мети, планування, організація праці, контроль, виявлення та виправлення помилок) важливими $є$ уміння виконувати завдання не лише індивідуально, але й в умовах спільної праці.

Культура праці формується в навчально-виробничій і трудовій діяльності, де пріоритетними завданнями $є$ розвиток у студентів інтелектуальних, духовноморальних, естетичних та інших цінностей у процесі їхньої навчально-пізнавальної та творчої діяльності, що реалізується у різних формах педагогічного процесу. Водночас взаємозв'язок самостійної і керованої діяльності 3 іншими видами виробничої 
діяльності студентів стає психологічною основою єдності та безперервності їхнього навчання та виховання, де мають місце планування професійного розвитку студентів, зростання їхньої професійної культури, зокрема культури праці. Виховання культури праці у процесі виробничого навчання передбачає розвиток самостійної і творчої активності студентів. А це можливо, коли виконавчий акт перетворюється на акт самостійного пошуку, творення за власним задумом тощо.

Одним із вирішальних критеріїв ефективності творчої і самостійної праці студентів $\epsilon$ ступінь розвитку в них свідомого, цілеспрямованого самоконтролю й самоорганізації, саме тому формування уміння планувати свою працю й самоконтроль ми розглядаємо як необхідні ланки в підготовці студентів до активної творчої і самостійної діяльності.

Власна практика та досвід роботи на технолого-педагогічному факультеті Криворізького педагогічного інституту підтверджує ці положення. Крім того, наголошуємо на тому, що самостійність праці є критерієм визначення рівня розвитку культури праці - це власний спосіб мислення студента, його властивість, яка пояснює характер його вчинків.

Предметом нашого дослідження став ступінь самостійності студентів технологопедагогічного факультету (загальна кількість - 87 осіб, 3 них: експериментальна група - 41, контрольна група - 46) у виконанні творчих завдань, ми намагалися виявити умови, за яких здійснюється розвиток самостійності студентів як їхньої особистісної професійно значущої якості. Результати дослідження представлено в табл. 1 .

Таблиия 1

Інтенсивність виявів самостійності учнів у навчальній діяльності

\begin{tabular}{|c|c|c|c|c|c|c|c|c|}
\hline \multirow{3}{*}{ Рівні виявів у: } & \multicolumn{8}{|c|}{$\begin{array}{c}\text { Частота виявів самостійності студентів } \\
\text { (загальна кількість студентів }-87, \mathrm{E} \Gamma-41, \text { КГ - 46) }\end{array}$} \\
\hline & \multicolumn{2}{|c|}{ Інтенсивна } & \multicolumn{2}{|c|}{ Ситуативна } & \multicolumn{2}{|c|}{ Епізодична } & \multicolumn{2}{|c|}{ Не виявляється } \\
\hline & EK & КГ & EK & КГ & EK & КГ & EK & КГ \\
\hline Мотивації & $55 \%$ & $51 \%$ & $30 \%$ & $33 \%$ & $11 \%$ & $16 \%$ & $4 \%$ & $6 \%$ \\
\hline Плануванні & $32 \%$ & $52 \%$ & $45 \%$ & $27 \%$ & $10 \%$ & $14 \%$ & $5 \%$ & $14 \%$ \\
\hline Виконанні творчих завдань & $44 \%$ & $49 \%$ & $31 \%$ & $36 \%$ & $16 \%$ & $9 \%$ & $3 \%$ & $2 \%$ \\
\hline Самоконтролі & $25 \%$ & $41 \%$ & $40 \%$ & $28 \%$ & $18 \%$ & $21 \%$ & $10 \%$ & $11 \%$ \\
\hline
\end{tabular}

У запропонованій анкеті щодо вивчення виявів самостійності студентів у навчальній діяльності ми спиралися на основні компоненти культури парці. Констатувальний експеримент показав, що найінтенсивніше вона виявляється в мотивації навчально-трудового процесу. Студенти переважно у практиці використовують набуті у процесі навчально-виробничої діяльності знання, уміння та навички. Менше вдається виявити самостійність у плануванні навчально-трудової діяльності та здійсненні самоконтролю, оскільки традиційно підтримуються звички покладання відповідальності за здійснення контролю на викладача, який має вказувати на недоліки в роботі.

Саме тому в сучасній системі професійної освіти велике значення надається формам і методам самостійної роботи студентів, що актуалізує роль їхньої самооцінки та самоконтролю за власними діями і професійним розвитком. 3-поміж різних якісних показників успішності формування самоконтролю ми визначили такі:

- час, витрачений студентами на контроль; 
- правильність визначення помилок і причин їх виникнення;

- правильне виконання прийомів самоконтролю.

Кількісними показниками рівня самоконтролю за формуванням культури праці $є$ критерій надійності, який має такі показники:

- час перебігу між двома наступними помилками;

- загальна кількість помилок на певний відрізок часу;

- відсоток безпомилкового виконання дій.

У самостійній роботі студентів формуються трудові уміння i навички, виявляються нахили та здібності, виховуються професійні якості особистості, необхідні задля успішного здійснення майбутньої професійної діяльності. У контрольній групі студентів ми традиційно здійснювали оперативний контроль за діяльність кожного студента, надавали індивідуальну допомогу тим, хто ії̈ потребував, при необхідності проводили додатковий інструктаж, вказували на допущені помилки і пояснювали, чим вони викликані та як краще їх виправити.

У експериментальній групі, згідно з завданнями нашої дослідної роботи, під час традиційного ходу проведення самостійної роботи і здійснення контролю за іiі виконанням, ми регулярно звертали увагу студентів на особистісний смисл виконуваної роботи і те, яке це значення має здійснення цих завдань у формуванні культури праці. Отже, процес формування культури праці набував умотивованого характеру й усвідомлювався студентами.

Результати самостійної діяльності в експериментальній групі ми порівняли 3 роботою контрольної групи студентів. За інших однакових умовах організації самостійної роботи якісні показники виконання однакових завдань в експериментальних групах від етапу до етапу формування культури праці ставали вищими. Це надає нам підстави стверджувати, що використання методу смислової регуляції стимулює розвиток культури праці, а також ефективно впливає на ставлення студентів до самостійної діяльності, власного професійного розвитку, на встановлення творчих взаємин тощо.

Задля визначення одного 3 компонентів культури праці- самостійності у роботі- студентам було запропоновано завдання: розробити творчий проект $\mathrm{i}$ виготовити художній виріб (на матеріалі навчальної дисципліни «Елементи декоративно-прикладного мистецтва»). За змістом завдання було однакове для всіх студентів, але за складністю- різне. Це залежало від професійної підготовки студентів та їхніх творчих здібностей. У контрольній групі процес проходив традиційно, в експериментальній - ми намагалися використовувати методи смислової регуляції, проводили додаткові інструктажі, вказівки до самостійного виконання завдання, обов'язково залишаючи місце для творчих роздумів, збільшували коло проблемних ситуацій, де рішення студенти повинні знайти самостійно. Під час інструктажу викладач постійно мотивував студентів на розвиток культури праці, активної інтелектуальної і творчої діяльності, щоб студент виконував самостійну роботу із задоволенням, усвідомлюючи особистісний смисл власної праці. Ми звернули увагу, що самостійність та ініціативність студентів успішно формувалася, коли викладач при необхідності допомагав планувати свою працю. Функції визначення конкретних завдань і плану роботи викладач поступово перекладав на студентів. Порівняльний аналіз результатів проведеної роботи представлено у табл. 2 . 
Порівняльні результати самостійної роботи студентів експериментальних та контрольних груп

\begin{tabular}{|c|c|c|c|}
\hline \multirow{2}{*}{$\begin{array}{l}\text { № } \\
\Pi / \Pi\end{array}$} & \multirow[t]{2}{*}{ Вид діяльності } & \multicolumn{2}{|c|}{$\begin{array}{c}\text { Результати (загальна кількість } \\
\text { студентів }-87, \mathrm{E} \Gamma-41, \mathrm{~K} \Gamma-46)\end{array}$} \\
\hline & & $\mathrm{E} \Gamma$ & КГ \\
\hline 1. & \begin{tabular}{|l} 
Планування та поетапна \\
роботи над творчим проектом
\end{tabular} & $85 \%$ & $43 \%$ \\
\hline 2. & Процес створення проекту & $67 \%$ & $50 \%$ \\
\hline 3. & Захист проекту & $100 \%$ & $64 \%$ \\
\hline 4. & $\begin{array}{|lcc|}\text { Обгрунтування ідеї } & \text { та } & \text { технології } \\
\text { виготовлення виробу } & & \\
\end{array}$ & $86 \%$ & $69 \%$ \\
\hline 5. & Презентація виробу (захист) & $100 \%$ & $79 \%$ \\
\hline
\end{tabular}

Як бачимо, за результатами впровадженої методики, ми зафіксували позитивну динаміку розвитку самостійності студентів.

Отже, аналіз результатів нашої роботи підтвердив доцільність використання запропонованих прийомів розвитку самостійності студентів ВНЗ. Можемо зробити висновок, що розвиток професійної самостійності як компонента культури праці відбувається більш успішно, коли у процесі навчально-пізнавальної діяльності перед студентами ставляться такі завдання, які розв'язати відомим способом не вдається, i залишається шлях творчого й самостійного пошуку. Перспективою подальших досліджень убачаємо розроблення спецкурсів з розвитку культури праці під час вивчення окремих дисциплін на технолого-педагогічному факультеті.

\section{Література}

1. Блонский П.П. Трудовая школа / П. П. Блонский. - М. : Педагогика, 1976. 249 с. 2. Тхоржевський Д. О. Місце та завдання трудового виховання у системі виховання школярів / Д. О. Тхоржевський // Трудова підготовка в закладах освіти України. - 1995. - № 1. - С. 6-8. 3. Шацкий С. Т. Педагогические сочинения: в 4 т. / С.Т. Шацкий. - Т. 1. -395 с.

УДК 378

Олександр Сушенцев

\section{УМОВИ ФОРМУВАННЯ КОНКУРЕНТОЗДАТНОСТІ МАЙБУТНІХ ЕЛЕКТРОМЕХАНІКІВ У НАВЧАЛЬНО-ВИХОВНОМУ ПРОЦЕСІ ВНЗ}

Сушенцев О. О. Умови формування конкурентоздатності майбутніх електромеханіків у навчально-виховному процесі ВНЗ.

Розглянуто проблему формування конкурентоздатності майбутніх електромеханіків у ВНЗ І-ІІ рівня акредитації. Здійснено теоретичний аналіз науковопедагогічної літератури, присвяченої вивченню педагогічних умов формування конкурентоздатності фахівців в навчально-виховному процесі вищого навчального закладу.

Ключові слова: конкурентоздатність, педагогічні умови, майбутній електромеханік.

Сушенцев А. А. Условия формирования конкурентоспособности будущих электромехаников у навчально-виховному процессе ВУЗА.

Рассмотрена проблема формирования конкурентоспособности будущих 